\title{
Effect of roasting time on physicochemical characteristics and antioxidant activity of hot water extracts of dried Liriope platyphylla
}

\author{
Min-Jung Kang, Dyeong-Wha Kim, Jae-Ran Kang, Jung-Hye Shin \\ Namhae Garlic Research Institute, Namhae 52430, Korea
}

\section{덖음 시간을 달리한 건조 맥문동 열수추출물의 이화학적 특성 및 항산화 활성}

\author{
강민정 · 김경화 · 강재란 · 신정혜* \\ (재) 남해마늘연구소
}

\begin{abstract}
This study was performed in order to determine the effect of roasting $\left(160^{\circ} \mathrm{C}\right.$ for $\left.0,30,60,90 \mathrm{~min}\right)$ on the physicochemical characteristics and antioxidant activity of hot water extracts of dried Liriope platyphylla. With respect to Hunter's color value, lightness and yellowness decreased roasting time increased. The difference $(\Delta \mathbf{E}$ value) in lightness, redness and yellowness was 15.88 and 22.94 for 30 and $60 \mathrm{~min}$. The 30 min roasted sample contained more soluble solid content $\left(12.7^{\circ} \mathrm{Brix}\right)$ than other samples. The $\mathrm{pH}$ and acidity of the 60 min roasted sample were 5.06 and $\mathbf{0 . 1 4} \%$, respectively. The highest contents in reducing sugar and total phenolic compounds contents was obsemed in the $60 \mathrm{~min}$ roasted sample $(17.68$, and $35.01 \mathrm{~g} / 100 \mathrm{~g}$, respectively), and flavonoid content was the highest in the $90 \mathrm{~min}$ roasted sample $(10.53 \mathrm{mg} / 100 \mathrm{~g})$. The crude saponin content of the 90 min roasted sample $(21.90 \mathrm{mg} / 100 \mathrm{~g})$ was higher than that of others samples $(8.0-15.36 \mathrm{mg} / 100 \mathrm{~g})$. Moreover, ginsenosides such as Re, Rg3, and Rh2, were detected, among which the Rh2 content was the highest. The 2,2-diphenyl-1-picrylhydrazyl (DPPH) radical scavenging activity (31.64-53.72\%), 2,2'-azinobis(3-ethylbenzothiazoline)-6-sulfonic acid (ABTS) radical scavenging activity (61.59-96.71\%), and the ferric reducing antioxidant power (72.38-183.11\%) were higher in the roasted samples than in the control group. As a result, we confirmed that roasting increased the amount of active compounds, which increased the yield of useful extract.
\end{abstract}

Key words : Liriope platyphylla, total phenolic compounds, crude saponin, ginseniside contents, roasting

\section{서 론}

맥문동(Liriope platyphylla)은 백합과에 속하는 다년생 초본 약용식물로 우리나라, 중국, 일본, 대만 등에 분포하며, 주로 덩이뿌리를 한약재로 이용하는데 한국산 맥문동 (Liriope platyphylla Wang et Tang), 개맥문동(Liriope spicata L.) 및 소엽맥문동(Ophiopogon japonicus K. G.)으로 구별된 다(1). 식품공전 중 식품에 제한적으로 사용할 수 있는 원료

*Corresponding author. E-mail : whanbee@daum.net Phone : 82-55-860-8947, Fax : 82-55-860-8960

Received 28 February 2018; Revised 12 April 2018; Accepted 19 April 2018.

Copyright (c) The Korean Society of Food Preservation. All rights reserved.
의 목록에 수록되어 있어, 식품 제조·가공시 부원료로 사용 할 수 있는 식물 중 하나이다(2). 맥문동은 가늘고 긴 수염뿌 리 끝에 형성된 짧은 방추형의 괴근을 이용하는 식물로 신농본초경에는 진해거담, 자양강장 등에 사용되는 약재 로, 본초강목에는 몸을 보하는 보약으로서 성질은 약간 차 고 독이 없으며, 맛은 달고 약간 쓰고, 자양강장, 이뇨, 지갈, 만성 기관지염, 만성 인후염 및 폐결핵 등의 치료에 사용되 는 것으로 기록되어 있다(3). 최근 들어 맥문동은 혈당강하, 당뇨예방, 기억력 증진, 항염증, 미생물 생육억제 기능이 있다고 알려져 있으며(4), 주요 생리활성 성분으로는 스테 로이드계 사포닌(steroidal saponin)인 spicatoside 및 ophipogonin이 있고 그 외 $\beta$-sitosterol, stigmasterol, $\beta$ -sitosterol glucoside, oligsaccharides 등 다양한 polysaccharides 가 함유되어 있다(5). 
맥문동과 관련해서는 영양특성 및 생리기능성(6,7), 사포 닌 성분 분석(8), 전처리에 따른 항산화 활성과 관능적 특성 (9)이 연구되어 있으며, 약리학적인 효능으로는 항염증 효 과(10), 빼 파괴 세포 분화에 미치는 효능(11), 면역조절 효과(12)가 확인되어 있다. 맥문동의 스테로이드 사포닌 중 spicatoside $\mathrm{A}$ 는 암세포에 대한 생장억제 활성이 가장 높고(13), 부탄올 추출물은 뇌 조직에서 신경세포의 생존과 성장에 긍정적인 영향을 미치며(14), 열수 추출물은 사염화 탄소로 유발된 흰쥐의 간 손상에 대한 보호 효과가 있다고 보고되어 있고(15), 발효음료(16), 인삼정과(17), 바게트 빵 (18)에 적용하여 품질 특성에 미치는 영향에 관한 연구가 진행되어 있다.

다양한 생리활성을 지니는 천연식물류는 주로 건조된 상태로 보관되는데 일부 원료의 경우 소량의 유해한 성분을 함유하고 있기도 하여 전처리 과정을 거쳐 사용된다. 민간 이나 한방에서는 원료의 독성이나 부작용을 제거함으로써 단점을 보완하고, 화학적 반응을 유도하여 약성을 높이기 위해 다양한 방법으로 법제라는 전처리 과정을 적용하고 있다 $(19,20)$. 법제를 위한 처리 방법으로는 따뜻한 물에 씻 거나, 끓는 물에 불려서 심을 제거하거나, 술에 담갔다가 찹쌀에 버무려서 쪄서 사용하거나, 생강즙에 볶아서 쓰는 방법과 즙을 내어 고를 만들어 사용하는 등 다양한 방법이 알려져 있다(21).

맥문동의 경우도 전분 함량이 $50 \%$ 이상으로 높아 저장 중 부패와 생물적 위해요소에 노출되기 쉬우므로 수확 후 신속하게 건조시켜(22) 여러 방법으로 법제과정을 거쳐 사 용 된다. 하지만 실제 이러한 전처리 과정을 거친 맥문동의 기능성이나 생리활성 변화에 대해서는 아직도 많은 연구가 진행되어 있지 않고, 맥문동은 다양한 효능에도 불구하고 그 자체로 활용되기 보다는 주로 여름철 건강 음료인 생맥 산의 재료로 사용되거나 다른 한약재와 혼합하는 부재료로 사용되고 있어 그 활용성이 높지 않다(23). 따라서 본 연구 에서는 건열 덖음 처리 정도가 맥문동의 주요 이화학적 성분 및 항산화 기능성의 변화에 미치는 영향을 확인함으로 써 맥문동의 활용성과 가공적성을 확대하기 위한 기초자료 로 활용하고자 하였다.

\section{재료 및 방법}

\section{실험재료 및 추출물의 제조}

맥문동은 재배 농가 협회(한뜻약재)에서 생산하여 품질 관리된 제품 중 밀양산을 건조하여 포장된 상태로 구입하여 사용하였다. 맥문동 $600 \mathrm{~g}$ 을 지름 $28 \mathrm{~cm}$, 높이 $15 \mathrm{~cm}$ 의 용기에 담아 용기 내부 온도는 $160 \pm 5^{\circ} \mathrm{C}$, 맥문동의 중심 온도는 $100 \pm 5^{\circ} \mathrm{C}$ 를 유지하면서 각각 30,60 , 및 90 분간 계속 해서 저어주면서 건열 덖음 처리 하였다. 덖음 처리된 맥문
동은 식힌 후 건조 시료의 무게 대비 7.5 배의 물을 가하여 추출물을 제조하였다. 맥문동에 물을 가하여 강한 불에서 15 분간 끓이다가 이후부터는 $96^{\circ} \mathrm{C}$ 정도의 온도를 유지하면 서 75 분간 더 가열한 다음 여과하여 추출물을 완성한 후 여과지로 여과하여 실험에 사용하였다. 이 때 덖음 처리하 지 않은 맥문동을 동일한 조건에서 추출 여과한 것을 대조 군으로 하였다.

\section{색도 측정}

각각의 추출액의 색도는 색차계(Ultra scan VIS, Hunter Lab., Reston, VA, USA)를 이용하여 측정하였다. 이 때 표준 색판의 $\mathrm{L}, \mathrm{a}, \mathrm{b}$ 값은 각각 $99.41,-0.13$ 및 0.06 이었으며, 각 시료는 0 시간 처리를 대조구로 하여 5 회 이상 반복 측정 값으로 $\mathrm{L}, \mathrm{a}, \mathrm{b}$ 와 $\Delta \mathrm{E}$ 값으로 산출하여 평균값으로 나타내었 다.

\section{가용성 고형분 함량, $\mathrm{pH}$ 및 산도 측정}

가용성 고형분은 여과한 시료액을 일정량 취하여 자동굴 절당도계(PR-201 a, Atago, Minato, Tokyo, Japan)로 3회 반복 측정하였다. $\mathrm{pH}$ 와 산도는 추출액 $1 \mathrm{~mL}$ 를 취하여 자동 적정기(G20 compact titrator, Mettler toledo, Langacher, Greifensee, Switzerland)를 이용해 동시에 분석하였다.

\section{환원당, 총 페놀 화합물 및 총 플라보노이드 정량}

DNS법에 따라 추출액 $1 \mathrm{~mL}$ 를 취하여 DNS 시약 $3 \mathrm{~mL}$ 를 가한 후 끓는 물에서 15 분간 중탕 가열 한 다음 찬물에서 냉각하여 $570 \mathrm{~nm}$ 에서 흡광도를 측정하였다. Glucose (Sigma-Aldrich Co., St. Louis, MO, USA)를 표준물질로 하 여 작성한 검량곡선을 이용하여 정량하였다.

추출액 $1 \mathrm{~mL}$ 에 Foline-Ciocalteau 시약 $0.5 \mathrm{~mL}$ 를 넣고 3 분 후 $10 \% \mathrm{Na}_{2} \mathrm{CO}_{3}$ 용액 $0.5 \mathrm{~mL}$ 씩을 가한 후 혼합하여 실온의 암실에서 1 시간 정치한 다음 분광광도계(Libra $\mathrm{S}$ 35, Biochrom, Cambridge, Cambridgeshire, England)로 760 $\mathrm{nm}$ 에서 흡광도를 측정하였으며, 표준물질로 gallic acid (Sigma-Aldrich Co.)를 사용하여 시료와 동일한 방법으로 분석하여 얻은 검량선으로부터 총 페놀 화합물의 함량을 계산 하였다.

총 플라보노이드 함량은 시료액 $50 \mu \mathrm{L}$ 에 $1 \mathrm{~N} \mathrm{NaOH} 50$ $\mu \mathrm{L}$ 를 넣고 diethylene glycol $200 \mu \mathrm{L}$ 를 혼합하여 vortexing 한 후 $37^{\circ} \mathrm{C}$ 인큐베이터에서 5 분간 반응시킨 다음 $420 \mathrm{~nm}$ 에 서 흡광도를 측정하였다. 이 때 rutin(Sigma-Aldrich Co.)을 표준물질로 하여 얻은 검량선으로부터 총 플라보노이드 함량을 계산하였다.

\section{조사포닌 정량}

시료 $5 \mathrm{~g}$ 을 증류수 $30 \mathrm{~mL}$ 에 용해시킨 후 ethyl ether 50 $\mathrm{mL}$ 로 씻은 다음 증류수층을 회수하여 butanol $50 \mathrm{~mL}$ 로 
3회 추출하였다. 미리 항량을 구한 한 농축플라스크에 추출 액을 옮겨 감압 농축하여 butanol을 제거한 후 $70^{\circ} \mathrm{C}$ 항온기 에서 1 시간 동안 건조하고 항량을 구하였다. 조사포닌 함량 은 butanol층을 농축 건조한 후의 플라스크 무게 $(\mathrm{mg})$ 에서 항량으로 한 빈 플라스크의 무게 $(\mathrm{mg})$ 를 뺀 값을 시료채취량 $(\mathrm{g})$ 으로 나누어 산출하였다.

\section{진세노사이드 정량}

시료 $3 \mathrm{~g}$ 을 $50 \mathrm{~mL}$ 튜브에 넣고 $30 \mathrm{~mL}$ 의 $50 \% \mathrm{MeOH}$ 을 첨가한 후 15 분 동안 초음파 추출하여 여과하였다. Sep-Pak Plus $\mathrm{C}_{18}$ cartridge를 $3 \mathrm{~mL} \mathrm{MeOH}$ 로 서서히 용출시켜 conditioning을 하고 다시 $3 \mathrm{~mL}$ 증류수로 2차 conditioning 시켰다. 추출 시료액 $2 \mathrm{~mL}$ 을 cartridge에 loading하고 10 $\mathrm{mL}$ 증류수로 서서히 용출하여 당류 등을 제거하였다. 이 cartridge에 메탄올 $2 \mathrm{~mL}$ 를 처리하여 서서히 ginsenoside 성분을 용출한 후 $0.45 \mu \mathrm{m}$ membrane filter로 여과하였다. Ginsenoside 함량은 HPLC-DAD(Agilent 1260, Agilent Technologies, Santa clara, CA, USA)로 분석하였다. 분석 컬럼은 Agilent Zorbax SB- $\mathrm{C}_{18}(4.6 \times 250 \mathrm{~mm}, 5 \mu \mathrm{m}$, Agilent Technologies)을 사용하고, 이동상의 유속은 $0.8 \mathrm{~mL} / \mathrm{min}$, 컬럼 온도는 $40^{\circ} \mathrm{C}, \mathrm{UV}$ 검출기의 검출파장은 $203 \mathrm{~nm}$ 로 하여 분석하였다.

\section{$\mathrm{DPPH}$ 라디칼 소거활성 측정}

1,1-Diphenyl-2-picrylhydrazyl(DPPH) 라디칼 소거활성 은 $\mathrm{DPPH}$ 에 대한 전자공여 활성으로 시료의 항산화 활성이 높을수록 보라색의 시약이 탈색이 되는 원리를 이용한 Blois의 방법(24)을 변형하여 에탄올로 $1.5 \times 10^{-4} \mathrm{M}$ 농도가 되도록 조절한 $\mathrm{DPPH}$ 용액 $100 \mu \mathrm{L}$ 와 시료 $100 \mu \mathrm{L}$ 를 혼합한 다음 실온에서 20 분간 반응시킨 후 분광광도계를 이용하여 $525 \mathrm{~nm}$ 에서 흡광도를 측정하여 시료 무첨가구에 대한 시료 첨가구의 흡광도비로 계산하여 \%로 나타내었다.

\section{$\mathrm{ABTS}$ 라디칼 소거활성 측정}

2,2'-Azino-bis(3-ethylbenzothiazoline-6-sulphonic $\mathrm{acid}$ (ABTS) 라디칼 소거능은 $\operatorname{Re}$ 등(25)의 방법에 따라 7 $\mathrm{mM}$ ABTS 용액에 potassium persulfate를 $2.4 \mathrm{mM}$ 이 되도록 용해시킨 다음 암실에서 12-16시간 동안 반응시킨 다음 $415 \mathrm{~nm}$ 에서 흡광도가 1.5 가 되도록 증류수로 희석하였다. 이 용액 $100 \mu \mathrm{L}$ 에 농도별 시료액을 $100 \mu \mathrm{L}$ 를 가하여 실온에 서 5 분간 반응시킨 후 $415 \mathrm{~nm}$ 에서 흡광도를 측정하였으며, $\mathrm{ABTS}$ 라디칼 소거능은 시료첨가구와 무첨가구의 흡광도 비로 나타내었다.

\section{FRAP 활성 측정}

Ferric-reducing antioxidant power(FRAP)에 의한 항산화 활성의 측정은 환원력을 이용한 방법으로 Benzie와 Strain
의(26) 방법을 응용하여 측정하였다. Reaction solution은 $300 \mathrm{mM}$ acetate buffer(pH 3.6), $40 \mathrm{mM} \mathrm{HCl}$ 에 녹인 $10 \mathrm{mM}$ 2,4,6-tris(2-pyridyl)-s-triazine(TPTZ) 및 $20 \mathrm{mM}$ iron(III) chloride를 10:1:1로 실험직전에 만들어 사용하였다. 시료액 $40 \mu \mathrm{L}$, 증류수 $40 \mu \mathrm{L}$, reaction solution $100 \mu \mathrm{L}$ 를 차례로 혼합하여 $37^{\circ} \mathrm{C}$ 에서 5 분간 반응시킨 후 $593 \mathrm{~nm}$ 에서 흡광도 를 측정하였으며, $\mathrm{FeSO}_{4} \cdot 7 \mathrm{H}_{2} \mathrm{O}$ 를 표준물질로하여 환원력 을 계산하였다.

\section{통계처리}

모든 실험은 3 회 이상 반복하여 실시하였으며 실험으로 부터 얻은 결과는 SPSS 18.0(IBM Corporation, Endicott, $\mathrm{NY}, \mathrm{USA})$ 을 사용하여 분석하였다. 결과치는 실험군당 평 균표푼편차로 표시하였고, 통계적 유의성 검정은 일원배 치 분산분석 한 후 $p<0.05$ 수준에서 Duncan's multiple range test를 시행하였다.

\section{결과 및 고찰}

색 도

덖음 처리 시간을 달리한 맥문동 추출물의 색도 변화는 Table 1 과 같다. $\mathrm{L}$ (명도) 값은 덖음 처리 시간이 증가함에 따라 감소하는 경향이었는데 대조구가 48.89 이던 것이 60 분간 덖음 처리하였을 때에는 30.69 로 약 $37 \%$ 가 감소하였 고 90 분간 덖음 처리시에는 26.32 로 가장 낮았다. a(적색도) 값은 덖음 처리 60 분까지 유의적으로 증가하여 12.31 로 가 장 높았으나 90 분간 덖음 처리하였을 때는 오히려 낮아져 60 분 처리시보다 약 $54 \%$ 가 감소하였다. 무처리 맥문동 추 출물의 $\mathrm{b}$ (황색도) 값은 17.90 이던 것이 30 분간 처리한 추출 물에서 21.00 로 가장 높았고, 60 분간 덖음 처리하였을 때는 $10.68,90$ 분 처리시에는 2.94 로 급격히 감소하였다. 덖음 처리에 따른 종합적인 색차는 $\Delta \mathrm{E}$ 값으로 추출물의 색차는 30 분간 덖음 처리시에는 15.88 정도 차이가 있었으며 60 분 간 처리시에는 대조구에 비해서는 22.94로 차이가 있었다.

$\mathrm{Bae}$ 등(27)은 $150-190^{\circ} \mathrm{C}$ 에서 맥문동을 로스팅 하였을 때 로스팅 온도가 높아짐에 따라 명도는 감소하고, 적색도는 증가하는데, 황색도는 $190^{\circ} \mathrm{C}$ 가열시는 오히려 감소한다고 하였고, Lee 등(28)은 열처리 온도와 시간을 달리한 홍삼 추출물의 명도는 온도가 높아지고, 처리 시간이 길어질수 록 감소하며 적색도는 명도와 반대의 경향이며, 황색도는 적색도와 유사한 경향을 보이지만 일정 온도나 시간 이상으 로 가열되었을 때는 오히려 감소한다고 보고하였다. 이들 의 연구결과는 본 연구 결과의 명도와 황색도는 일치하는 경향이었으나 적색도의 변화는 차이가 있었다. 이러한 차 이는 짧은 시간 동안 덖음 처리하였을 때는 열에 의해 맥문 동의 색이 선명해지고, 갈색화가 부분적으로 진행되면서 
적색도와 황색도가 증가하지만 덖음 시간이 길어지면서 갈변 반응 물질이 과량으로 생성됨으로 인해 적색도와 황색 도가 오히려 감소된 결과로 생각된다.

Table 1. Hunter color value of water extract from Liriope platyphylla at various roasting time

\begin{tabular}{ccccc}
\hline $\begin{array}{c}\text { Roasting time } \\
(\text { min })\end{array}$ & $\mathrm{L}$ & $\mathrm{a}$ & $\mathrm{b}$ & $\Delta \mathrm{E}$ \\
\hline 0 & $48.89 \pm 0.01^{1 \mathrm{D} 2)}$ & $-0.07 \pm 0.01^{\mathrm{A}}$ & $17.90 \pm 0.02^{\mathrm{C}}$ & - \\
30 & $37.56 \pm 0.01^{\mathrm{C}}$ & $10.62 \pm 0.02^{\mathrm{C}}$ & $21.00 \pm 0.03^{\mathrm{D}}$ & $15.88 \pm 0.02^{\mathrm{A}}$ \\
60 & $30.96 \pm 0.02^{\mathrm{B}}$ & $12.31 \pm 0.01^{\mathrm{D}}$ & $10.68 \pm 0.03^{\mathrm{B}}$ & $22.94 \pm 0.02^{\mathrm{B}}$ \\
90 & $26.32 \pm 0.00^{\mathrm{A}}$ & $6.69 \pm 0.02^{\mathrm{B}}$ & $2.94 \pm 0.04^{\mathrm{A}}$ & $29.79 \pm 0.01^{\mathrm{C}}$
\end{tabular}

${ }^{1)}$ All values are mean $\pm \mathrm{SD}(\mathrm{n}=5)$.

${ }^{2) A-D}$ Means with different superscript within the same column are significantly different by Duncan's multiple range test $(\mathrm{p}<0.05)$.

\section{가용성 고형분, $\mathrm{pH}$ 및 산도}

덖음 처리 시간을 달리한 맥문동 추출물의 가용성 고형 분, $\mathrm{pH}$ 및 산도의 변화는 Table 2 와 같다. 맥문동 추출물의 가용성 고형분 함량은 무처리 시료에서 $8.7^{\circ} \mathrm{Brix}$ 였는데 덖음 처리를 통해 유의적으로 증가하여 $11.3-12.7^{\circ} \mathrm{Brix}$ 의 범위로 덖음 처리 시간이 길어질수록 고형분 함량은 유의적 으로 증가하였다. 이러한 결과는 건조만 거친 맥문동 보다 는 건조 후 볶음 처리한 맥문동에서 가용성 고형분 함량이 유의적으로 높았다는 Yang(21)의 보고와 일치하였는데 이 는 가열 중에 일어나는 전분의 열분해 현상 및 물리화학적 인 변화에 의해 전분이 수용성 물질로 변화되기 때문이라고 보고되어 있다(29).

덖음 처리 시간이 증가할수록 $\mathrm{pH}$ 는 감소하고 산도는 증 가하는 경향으로 $\mathrm{pH}$ 는 대조구에서 5.93이던 것이 유의적으 로 감소하여 60 분 덖음 처리구에서는 5.06 으로 90 분 덖음 처리한 시료와 유의적인 차이가 없었다. 이러한 결과는 인 삼의 열처리시 가열온도가 증가할수록 $\mathrm{pH}$ 가 낮아진다는 보고(30)와 유사한 경향이었다.

열처리 시 온도가 높아짐에 따라 $\mathrm{pH}$ 가 저하되는 원인은 환원당인 aldohexose의 aldehyde기가 산화로 인해 carbonyl

Table 2. Soluble solid content, $\mathrm{pH}$ and acidity of water extract from Liriope platyphylla at various roasting time

\begin{tabular}{cccc}
\hline $\begin{array}{c}\text { Roasting time } \\
(\mathrm{min})\end{array}$ & $\begin{array}{c}\text { Soluble solid } \\
\left({ }^{\circ} \text { Brix }\right)\end{array}$ & $\mathrm{pH}$ & $\begin{array}{c}\text { Acidity } \\
(\%)\end{array}$ \\
\hline 0 & $8.7 \pm 0.0^{1) \mathrm{A} 2)}$ & $5.93 \pm 0.02^{\mathrm{C}}$ & $0.09 \pm 0.01^{\mathrm{A}}$ \\
30 & $12.7 \pm 0.0^{\mathrm{D}}$ & $5.65 \pm 0.01^{\mathrm{B}}$ & $0.12 \pm 0.00^{\mathrm{B}}$ \\
60 & $12.1 \pm 0.0^{\mathrm{C}}$ & $5.06 \pm 0.04^{\mathrm{A}}$ & $0.14 \pm 0.00^{\mathrm{C}}$ \\
90 & $11.3 \pm 0.1^{\mathrm{B}}$ & $5.06 \pm 0.01^{\mathrm{A}}$ & $0.14 \pm 0.00^{\mathrm{C}}$ \\
\hline
\end{tabular}

\footnotetext{
${ }^{1)}$ All values are mean $\pm \mathrm{SD}(\mathrm{n}=3)$.

2)A-D Means with different superscript within the same column are significantly different by Duncan's multiple range test $(\mathrm{p}<0.05)$.
}

기를 생성하고, 염기성 아미노산이 당과 결합하여 갈변반 응에 관여함으로써 점차 가용 염기성 아미노산이 감소되기 때문이라고 보고되어 있는데(31) 본 연구의 결과에서도 $\mathrm{pH}$ 저하는 비효소적 갈변반응으로 인한 염기성 아미노산의 감소에 따른 것으로 추측된다.

\section{환원당, 총 페놀 화합물 및 플라보노이드 함량}

덖음 시간에 따른 맥문동의 가용성 환원당, 총 페놀 화합 물 및 플라보노이드 함량 변화는 Table 3 과 같다. 맥문동의 환원당 함량은 덖음 처리하지 않은 대조군이 $8.09 \mathrm{~g} / 100$ $\mathrm{mL}$ 이었고 30 분간 덖음 처리하였을 때에는 $12.59 \mathrm{~g} / 100 \mathrm{~mL}$ 로 크게 증가하였다. 또한 60 분간 덖음 처리 후에는 17.68 $\mathrm{g} / 100 \mathrm{~mL}$ 로 대조구에 비해 더 높은 함량이었다. 맥문동을 생으로 건조하거나 수증기나 술로 증숙한 후의 환원당 함량 은 이들 각각을 덖음 처리한 시료에서 유의적으로 더 높았 는데 이는 열분해로 인한 저분자량의 올리고당이나 덱스트 린과 같은 환원당의 생성량이 볶음 처리 과정 중에 소모되 는 양보다 현저히 많기 때문이라고 보고되어 있다(21). 본 연구의 결과에서도 동일한 경향으로 덖음 처리 과정을 거치 면서 맥문동의 조직이 변형되고, 열에 의해 일부 당의 결합 이 분해되며 추출하는 동안의 가열·팽윤으로 인하여 추출 이 보다 용이해 짐으로써(28) 덖음 시간이 길어질수록 환원 당의 함량이 더 증가한 것으로 판단된다.

페놀성 화합물은 식물계에 널리 분포되어 있는 물질로 다양한 구조와 분자량을 가지며 phenol hydroxyl기를 통해 항산화, 항암 및 항균 등의 생리기능을 가지는 것으로 알려 져 있다(32).

처리 시간을 달리하여 건열 덖음 한 맥문동의 총 페놀 화합물 함량은 대조군에서 $12.02 \mathrm{mg} / 100 \mathrm{~g}$ 이던 것이 60 분간 덖음 처리시 $35.01 \mathrm{mg} / 100 \mathrm{~mL}$ 로 가장 함량이 높았고, 90 분 덖음 처리 추출물은 대조군과 동일한 양으로 감소하였다.

맥문동의 덖음 처리에 따른 플라보노이드 함량은 덖음 처리 전 $1.33 \mathrm{mg} / 100 \mathrm{~mL}$ 이던 것이 덖음 처리 시간이 길어질 수록 유의적으로 증가하여 90 분간 덖음 처리 추출물에서는 $10.53 \mathrm{mg} / 100 \mathrm{~mL}$ 로 대조군 시료에 비해 높은 함량이었다.

이러한 결과는 열처리에 의해 식물체의 세포벽이 파괴됨 으로써 bound형 페놀성 화합물이 유리되어 폴리페놀과 플 라보노이드의 함량이 증가한다는 보고(33)와 동일한 경향 이었다.

도토리차 제조를 위하여 전처리 방법을 달리한 후 각각 덖음 처리하였을 때 총 페놀화합물 및 플라보노이드 함량이 증숙, 열풍건조, 덖음을 차례로 거친 시료에 비해 열풍건조 후 덖음 처리한 시료에서 더 높은 것은 전처리 공정이 유용 물질의 생성이나 용출에 도움을 주지만 과도할 경우 유용성 분의 파괴를 야기하여 성분의 감소를 가져오기 때문이라고 보고되어 있는데(34), 본 연구의 결과에서도 60 분 이상의 덖음 처리는 플라보노이드 화합물의 증가에는 기여하였으 나 페놀 화합물의 일부를 감소시켰다. 
Table 3. Reducing sugar, total phenolic compounds and flavonoides contents of water extract from Liriope platyphylla at various roasting time

\begin{tabular}{cccc}
\hline $\begin{array}{c}\text { Roasting time } \\
(\mathrm{min})\end{array}$ & $\begin{array}{c}\text { Reducing sugar } \\
(\mathrm{g} / 100 \mathrm{~mL})\end{array}$ & $\begin{array}{c}\text { Total phenolic compounds } \\
(\mathrm{mg} / 100 \mathrm{~mL})\end{array}$ & $\begin{array}{c}\text { Flavonoid } \\
(\mathrm{mg} / 100 \mathrm{~mL})\end{array}$ \\
\hline 0 & $8.09 \pm 0.04^{1) \mathrm{A} 2)}$ & $12.02 \pm 0.01^{\mathrm{A}}$ & $1.33 \pm 0.12^{\mathrm{A}}$ \\
30 & $12.59 \pm 0.08^{\mathrm{B}}$ & $25.01 \pm 0.00^{\mathrm{B}}$ & $3.47 \pm 0.09^{\mathrm{B}}$ \\
60 & $17.68 \pm 0.11^{\mathrm{C}}$ & $35.01 \pm 0.00^{\mathrm{C}}$ & $5.06 \pm 0.20^{\mathrm{C}}$ \\
90 & $16.75 \pm 0.03^{\mathrm{C}}$ & $12.01 \pm 0.00^{\mathrm{A}}$ & $10.53 \pm 0.04^{\mathrm{D}}$ \\
\hline
\end{tabular}

${ }^{1)}$ All values are mean $\pm \mathrm{SD}(\mathrm{n}=3)$

2)A-D Means with different superscript within the same column are significantly different by Duncan's multiple range test $(\mathrm{p}<0.05)$.

\section{조사포닌 함량}

맥문동 덖음 처리 시간에 따른 조사포닌 함량의 변화는 Fig. 1과 같다. 덖음 처리하지 않은 대조구의 조사포닌 함량 은 $8.0 \mathrm{mg} / 100 \mathrm{~mL}$ 이던 것이 덖음 처리 시간이 길어질수록 그 함량이 점차 증가하여 60 분 및 90 분간 덖음 처리시에는 각각 15.36 및 $21.90 \mathrm{mg} / 100 \mathrm{~mL}$ 으로 덖음 처리하지 않은 시료보다 약 $46.6 \%$ 및 $63.6 \%$ 가 증가하였다.

Lee 등(35)는 생맥문동에 비해 건조 맥문동의 조사포닌 함량은 약 2.3 배가 더 높고, 볶음 맥문동은 약 2.8 배 더 높았 는데, 이는 볶음처리 맥문동의 경우 주요 성분들의 변화가 일어나기 때문이라고 하였다. 맥문동 중의 주요 활성성분 중 하나인 steroid saponin은 맥문동 분말에 4 배의 물을 가하 여 가열 추출한 추출물에서는 $1.73 \%$ 정도로 이를 건물량으 로 환산할 경우 $6.92 \%$ 에 달해 일반적으로 알려져 있는 맥문 동의 조사포닌 함량에 비해 더 높은데, 이는 열수추출 시 steroid saponin 외에 다른 종류의 saponin도 함께 용출되었 기 때문이라고 보고되어 있다(36). 이러한 관점에서 볼 때 본 연구결과에서 맥문동의 saponin 함량은 덖음 처리할 경

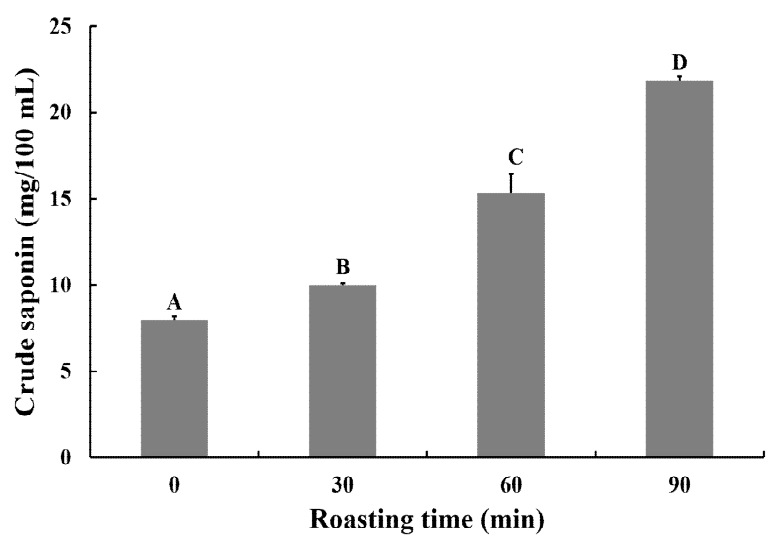

Fig. 1. Crude saponin contents of water extract from Liriope platyphylla at various roasting time.

All values are mean $\pm \mathrm{SD}(\mathrm{n}=3)$.

${ }_{A-D}$ Means with different superscript within the sample are significantly different by Duncan's multiple range test $(\mathrm{p}<0.05)$.
우 약 2 배 이상 더 증가하여 덖음 처리 공정이 맥문동 내의 saponin 용출에 유리하게 작용하는 것으로 판단된다.

맥문동의 괴경에는 steroid saponin, homo-isoflavonoid, sitosterol과 같은 생리활성물질이 함유되어 있는데(37), steroid saponin은 항암효과와 그 외 항염증, 미생물 생육억 제, 혈당강하, 항당뇨, 기억력 증진 등의 기능이 있다고 알려 져 있다 $(38,39)$. 특히 steroid계 saponin인 spicatoside A는 국내산 맥문동에만 함유되어 있으며(40), 신경돌기 성장에 효과가 있는 신경성장 인자의 주요물질이라고 보고되어 있다(41).

\section{진세노사이드 함량}

볶은 맥문동에서 진세노사이드 함량을 분석한 결과는 Table 4 와 같다. 총 11 종의 진세노사이드를 분석한 결과 $\mathrm{Re}, \mathrm{Rg} 3, \mathrm{Rh} 2$ 의 3종류만이 확인·정량되었다. 그 중 $\mathrm{Rh} 2$ 가 $8.32-8.84 \mathrm{mg} / 100 \mathrm{~mL}$ 의 범위로 가장 높은 함량이었고 다음 으로 Re가 3.89-7.67 mg/100 mL의 범위였다. 덖음 처리 시간이 증가할수록 진세노사이드 함량은 증가하는 경향으 로 90 분간 덖음 처리 시 진세노사이드 총량은 $20.73 \mathrm{mg} / 100$ $\mathrm{mL}$ 로 가장 높은 함량이었다.

$\mathrm{Nam}$ 등(42)은 흑삼 제조과정 중 증포 횟수에 따른 진세노 사이드 함량 변화에서 $\mathrm{Rb} 1, \mathrm{Rb} 2, \mathrm{Rc}, \mathrm{Rd}$ 는 구증구포 후 감소하는 반면 Rh1, Rk1, 및 $\mathrm{Rg} 3$ 는 증숙 처리 이전 극히 미량이거나 존재하지 않았으나, 증포 후 그 함량이 증가하 였는데 이는 증숙 공정을 거치는 동안 특정부위의 당이 떨어져 나가면서 구조적 변환에 의해 일부 화합물은 감소하 고 일부 화합물은 현저히 증가하기 때문이라고 하였다. 본 연구에서도 덖음 처리 공정을 거치면서 $\mathrm{Rh} 2$ 의 함량은 유의 적인 차이가 없었으나 $\operatorname{Re}$ 와 $\operatorname{Rg} 3$ 는 덖음 처리 전보다 60 분 간 덖음 처리 후 유의적으로 증가하였다.

Table 4. Ginsenoside contents of water extract from Liriope platyphylla at various roasting time

\begin{tabular}{ccccc}
\hline $\begin{array}{c}\text { Roasting time } \\
(\mathrm{min})\end{array}$ & $\mathrm{Re}$ & $\mathrm{Rg} 3$ & $\mathrm{Rh} 2$ & Total \\
\hline 0 & $4.09 \pm 0.54^{1) \mathrm{A} 2)}$ & $3.96 \pm 0.54^{\mathrm{B}}$ & $8.84 \pm 0.85^{\mathrm{A}}$ & $16.89 \pm 1.92^{\mathrm{A}}$ \\
30 & $3.89 \pm 0.13^{\mathrm{A}}$ & $3.26 \pm 0.26^{\mathrm{A}}$ & $8.52 \pm 0.32^{\mathrm{A}}$ & $15.67 \pm 0.77^{\mathrm{A}}$ \\
60 & $7.02 \pm 0.66^{\mathrm{B}}$ & $4.52 \pm 0.07^{\mathrm{C}}$ & $8.32 \pm 0.32^{\mathrm{A}}$ & $19.86 \pm 1.05^{\mathrm{B}}$ \\
90 & $7.67 \pm 0.61^{\mathrm{B}}$ & $4.57 \pm 0.35^{\mathrm{C}}$ & $8.49 \pm 0.30^{\mathrm{A}}$ & $20.73 \pm 1.25^{\mathrm{B}}$ \\
\hline
\end{tabular}

${ }^{1)}$ All values are mean \pm SD $(n=4)$.

2)ADDeans with different superscript within the same column are significantly different by Duncan's multiple range test $(\mathrm{p}<0.05)$.

\section{$\mathrm{DPPH}$ 라디칼 소거활성}

전자공여능 측정에 사용된 $\mathrm{DPPH}$ 는 자유라디칼로서 라 디칼을 환원시키는 능력이 크면 높은 항산화 활성 능력을 지닌 것으로 기대할 수 있고, 인체 내 활성 라디칼에 의한 
노화 등을 억제하는 척도로 이용되고 있다(43).

덖음 처리 시간에 따른 맥문동 추출물의 DPPH 라디칼 소거능은 Table 5와 같다. 대조구 맥문동 추출물의 $\mathrm{DPPH}$ 라디칼 소거능은 25,50 , 및 $100 \mu \mathrm{g} / \mathrm{mL}$ 의 농도에서 각각 $14.11,20.79$, 및 $37.31 \%$ 였는데, 덖음 처리 시간이 증가함에 따라 추출물의 $\mathrm{DPPH}$ 라디칼 소거능도 증가하여 90 분간 덖음 처리시에는 $53.72-90.41 \%$ 로 활성이 가장 높았다.

팥차(44)와 자색고구마(45)도 볶음 시간이 증가할수록 $\mathrm{DPPH}$ 라디칼 소거능이 유의적으로 증가하는 것으로 보고 되어 본 연구의 결과와 동일한 경향이었다. 이처럼 가열처 리 시간이 증가할수록 $\mathrm{DPPH}$ 라디칼 활성이 증가하는 것은 열처리에 의한 비효소적 갈변반응으로 갈색 반응생성물인 melanoidin의 항산화 효과에 의한 것으로 알려져 있다(46).

Table 5. DPPH radical scavenging activity of water extract from Liriope platyphylla at various roasting time

$(\%)$

\begin{tabular}{cccc}
\hline \multirow{2}{*}{$\begin{array}{c}\text { Roasting time } \\
(\text { min })\end{array}$} & \multicolumn{3}{c}{ Concentration $(\mu \mathrm{gg} / \mathrm{mL})$} \\
\cline { 2 - 4 } & 25 & 50 & 100 \\
\hline 0 & $14.11 \pm 0.96^{\left.1)^{1222) \mathrm{A} 3}\right)}$ & $20.79 \pm 0.48^{\mathrm{bA}}$ & $37.31 \pm 1.06^{\mathrm{CA}}$ \\
30 & $31.64 \pm 0.52^{\mathrm{aB}}$ & $55.17 \pm 1.30^{\mathrm{bB}}$ & $81.27 \pm 2.02^{\mathrm{cB}}$ \\
60 & $37.00 \pm 1.40^{\mathrm{aC}}$ & $64.79 \pm 4.78^{\mathrm{bC}}$ & $88.72 \pm 1.06^{\mathrm{CC}}$ \\
90 & $53.72 \pm 2.53^{\mathrm{aD}}$ & $81.80 \pm 3.22^{\mathrm{bD}}$ & $90.41 \pm 0.20^{\mathrm{cC}}$ \\
\hline
\end{tabular}

${ }^{1)}$ All values are mean $\pm \mathrm{SD}(\mathrm{n}=4)$.

2)a-c Means with different superscript within the same row are significantly different by Duncan's multiple range test $(\mathrm{p}<0.05)$.

${ }^{3) A-D}$ Means with different superscript within the same column are significantly different by Duncan's multiple range test $(\mathrm{p}<0.05)$.

\section{ABTS 라디칼 소거활성}

덖음 처리 시간을 달리한 맥문동 추출물의 ABTS 라디칼 소거능은 Table 6과 같다. 대조구의 ABTS 라디칼 소거능은 $25 \mathrm{\mu g} / \mathrm{mL}$ 농도에서 $27.90 \%$ 이던 것이 시료의 농도가 증가 할수록 활성도 증가하여 $100 \mu \mathrm{g} / \mathrm{mL}$ 농도에서는 $78.84 \%$ 였

Table 6. ABTS radical scavenging activity of water extract from Liriope platyphylla at various roasting time

$(\%)$

\begin{tabular}{cccc}
\hline \multirow{2}{*}{$\begin{array}{c}\text { Roasting time } \\
(\mathrm{min})\end{array}$} & \multicolumn{3}{c}{ Concentration $(\mu \mathrm{g} / \mathrm{mL})$} \\
\cline { 2 - 4 } & 25 & 50 & 100 \\
\hline 0 & $27.90 \pm 2.10^{1 \mathrm{12} 2) \mathrm{A} 3)}$ & $47.64 \pm 0.96^{\mathrm{bA}}$ & $78.84 \pm 0.31^{\mathrm{cA}}$ \\
30 & $61.59 \pm 1.10^{\mathrm{aB}}$ & $94.69 \pm 0.10^{\mathrm{bB}}$ & $100.23 \pm 0.03^{\mathrm{cB}^{\mathrm{B}}}$ \\
60 & $74.92 \pm 0.95^{\mathrm{aC}}$ & $99.09 \pm 0.05^{\mathrm{bC}}$ & $100.67 \pm 0.07^{\mathrm{CC}}$ \\
90 & $96.71 \pm 0.55^{\mathrm{aD}}$ & $100.89 \pm 0.07^{\mathrm{bD}}$ & $101.63 \pm 0.21^{\mathrm{c}^{\mathrm{D}}}$ \\
\hline
\end{tabular}

${ }^{1)}$ All values are mean \pm SD $(n=4)$.

2)a-c Means with different superscript within the same row are significantly different by Duncan's multiple range test $(\mathrm{p}<0.05)$.

${ }^{3) A-D}$ Means with different superscript within the same column are significantly different by Duncan's multiple range test $(p<0.05)$.
다. 덖음 처리 시간에 따른 맥문동 추출물의 ABTS 라디칼 활성은 덖음 시간의 증가에 따라 활성도 유의적으로 증가하 였는데 90 분간 덖음 처리한 시료가 다른 시료보다 활성이 우수하였고 $25 \mu \mathrm{g} / \mathrm{mL}$ 의 낮은 농도에서도 $96.71 \%$ 의 높은 활성을 보였다.

전처리 시간을 달리한 맥문동 열수추출물의 ABTS 라디 칼 소거활성은 볶음 처리를 거치지 않은 시료에 비해 볶음 처리를 거친 시료의 활성이 1.2-1.4배 정도 더 높았으며, 이러한 경향은 $\mathrm{DPPH}$ 라디칼 소거활성에서도 동일하여 볶 음 처리 시료에서 1.3-2.2배 더 높았다는 보고(21)는 본 연구 의 결과와도 유사한 경향이었다.

\section{FRAP 활성 측정}

FRAP는 colored ferrous TPTZ 복합체에 의해 ferric ion이 ferrous로 전환되어지는 과정을 분석함으로써 시료내의 항 산화력을 측정하는 방법으로 낮은 $\mathrm{pH}$ 에서 환원제에 의해 $\mathrm{Fe}^{3+}-\mathrm{TPTZ}$ 복합체가 $\mathrm{Fe}^{2+}-\mathrm{TPTZ}$ 으로 환원되는 원리에 기초 하여 대부분의 항산화제가 환원력을 가지고 있다는 점에 착안하여 고안되어진 방법이다(47).

덖음 처리 시간을 달리한 맥문동의 FRAP 활성을 살펴본 결과는 Table 7과 같다. 대조군의 FRAP는 $25 \mu \mathrm{g} / \mathrm{mL}$ 농도에 서 $9.36 \mu \mathrm{M}$ 이던 것이 $100 \mu \mathrm{g} / \mathrm{mL}$ 의 농도에서는 $100.16 \mu \mathrm{M}$ 로 약 11 배 더 높았다. 덖음 처리한 맥문동 추출물에서도 동일 한 경향으로 30 분간 덖음 처리 한 시료도 $25 \mu \mathrm{g} / \mathrm{mL}$ 농도에 서 FRAP는 $72.38 \mu \mathrm{M}$ 이었는데, $100 \mu \mathrm{g} / \mathrm{mL}$ 농도에서는 $290.28 \mu \mathrm{M}$ 로 약 4 배 더 활성이 증가하였다. FRAP는 덖음 처리 시간이 길어질수록 더 높아져 90 분간 덖음 처리 한 시료에서는 가장 낮은 농도인 $25 \mu \mathrm{g} / \mathrm{mL}$ 에서도 $183.11 \mu \mathrm{M}$ 로 활성이 유의적으로 높았으며, 최고 농도인 $100 \mu \mathrm{g} / \mathrm{mL}$ 에서 활성은 $609.05 \mu \mathrm{M}$ 로 증가하였다.

맥문동의 덖음 처리 시간이 증가함에 따라 항산화능이 증가한 것은 식품의 열처리 가공에 따른 다양한 화학적 변화에 의해 생리활성 물질이 증가하기 때문이라는 보고

Table 7. FRAP of water extract from Liriope platyphylla at various roasting time

$\left(\mathrm{FeSO}_{4} \cdot 7 \mathrm{H}_{2} \mathrm{O}\right.$ eq $\left.\mu \mathrm{M}\right)$

\begin{tabular}{cccc}
\hline \multirow{2}{*}{$\begin{array}{c}\text { Roasting time } \\
(\mathrm{min})\end{array}$} & \multicolumn{3}{c}{ Concentration $(\mu \mathrm{g} / \mathrm{mL})$} \\
\cline { 2 - 4 } & 25 & 50 & 100 \\
\hline 0 & $9.36 \pm .099^{1 \mathrm{la2}) \mathrm{A} 3)}$ & $42.42 \pm 0.46^{\mathrm{bA}}$ & $100.16 \pm 0.42^{\mathrm{cA}}$ \\
30 & $72.38 \pm 0.51^{\mathrm{aB}}$ & $157.21 \pm 3.36^{\mathrm{bB}}$ & $290.28 \pm 2.63^{\mathrm{cB}}$ \\
60 & $99.12 \pm 1.46^{\mathrm{aC}}$ & $211.76 \pm 1.24^{\mathrm{bC}}$ & $412.31 \pm 2.85^{\mathrm{CC}}$ \\
90 & $183.11 \pm 3.98^{\mathrm{aD}}$ & $366.58 \pm 3.38^{\mathrm{bD}}$ & $609.05 \pm 2.35^{\mathrm{cD}}$ \\
\hline
\end{tabular}

${ }^{1)}$ All values are mean \pm SD $(n=4)$.

2)-c-Means with different superscript within the same row are significantly different by Duncan's multiple range test $(p<0.05)$.

${ }^{3 A-D}$ Means with different superscript within the same column are significantly different by Duncan's multiple range test $(\mathrm{p}<0.05)$. 
$(48,49)$ 들로 미루어 볼 때 맥문동의 열처리로 과정 중에 생리활성 물질이 증가하고, 추출물 중으로 용출이 보다 용 이해졌기 때문으로 판단된다.

\section{요 약}

맥문동의 활용성과 가공적성을 향상을 위한 기초연구의 일환으로 건조 맥문동을 $160^{\circ} \mathrm{C}$ 에서 각각 $0,30,60,90$ 분간 덖음 처리한 후 열수 추출물을 제조하여 이화학적 특성과 항산화활성을 조사하였다. 덖음 처리된 맥문동 추출물의 명도, 적색도, 황색도의 색차인 $\Delta \mathrm{E}$ 값은 대조구에 비해 30 분 간 처리시 15.88정도 차이가 있었으며 60분간 처리시 22.94 로 증가하여 볶음 처리에 따라 $\Delta \mathrm{E}$ 값이 유의적으로 증가하 였다. 가용성 고형분은 30 분간 덖음 처리한 맥문동 추출물 이 $12.7{ }^{\circ} \mathrm{Brix}$ 로 가장 높았다. 덖음 시간이 길어질수록 $\mathrm{pH}$ 는 감소하였고 산도는 증가하였는데 덖음 30 분 및 90 분 처리 시 $\mathrm{pH}$ 와 산도는 각각 5.06 및 $0.14 \%$ 였다. 환원당과 총 페놀 화합물의 함량은 60 분간 덖음 처리한 맥문동 추출물에서 각각 $17.68 \mathrm{~g} / 100 \mathrm{~mL}$ 및 $35.01 \mathrm{mg} / 100 \mathrm{~mL}$ 로 가장 높았고 플라보노이드 함량은 90 분 덖음시 $10.53 \mathrm{mg} / 100 \mathrm{~mL}$ 로 가장 높았다. 덖음 맥문동 추출물의 조사포닌 함량은 덖음 처리 시간이 길어질수록 증가하여 90 분 덖음시 $21.9 \mathrm{mg} / 100 \mathrm{~mL}$ 로 가장 높았다. 덖음 처리된 맥문동 추출물 중의 진세노사 이드는 분석된 11 종 중 $\mathrm{Re}, \mathrm{Rg} 3, \mathrm{Rh} 2$ 의 3종만이 검출되었는 데, 이 중 $\mathrm{Rh} 2$ 의 함량이 가장 높았으며 60 분 이상 덖음 처리하였을 때 그 총량이 유의적으로 증가하였다. 덖음 맥 문동의 항산화 활성은 덖음 처리하지 않은 맥문동보다 더 높았고 덖음 처리 시간이 증가할수록 활성은 증가하였다.

\section{References}

1. Kim JH, Kim JE, Lee YK, Nam SH, Her YK, Jee SW, Kim SG, Park DJ, Choi YW, Hwang DY (2010) The extracts from Liriope platyphylla significantly stimulated insulin secretion in the HIT-T15 pancreatic $\beta$-cell line. J Life Sci, 20, 1027-1033

2. Food Code (2013) Ministry of Food and Drug Safety, Cheongju, Korea, p 1-6

3. Han DS (1993) Pharmacognosy. $5^{\text {th }}$ ed, Dongmyungsa, Seoul, Korea, p 148

4. Cho HJ, Hynn BK, Sonn YK, Park CW, Chun HJ, Song KC, Noh DC, Yoon KH, Lee DB (2013) Study on establish soil suitability class of Liriopis platyphylla. Korean J Soc Soil Sci Fert, 10, 65-66

5. Shin JS (2002) Saponin composition of Liriope platyphylla and Ophiopogon japonicus. Korean J Crop Sci, 47, 236-239

6. Seo SJ, Kim NW (2010) Physiological activities of leaf and root extracts from Liriope platyphylla. Korean J Food Preserv, 17, 123-130

7. Lee GD, Kim JO, Son JH, Kim HY (2012) Monitoring on physicochemical properties of Liriope platyphylla by the use of four dimensional response surface. Korean J Food Preserv, 19, 560-568

8. Sung JD (2003) Characteristic analysis of collected genetic resources of Liriope species and development of cultivation system. Ph D Thesis, Dong-a University, Korea, p 23-25

9. Kim GW, Kang MJ, Kang JR, Shin JH (2018) Physicochemical characteristics of Sengmaksan added with Liriope platyphylla roasted for different times. Korean J Food Preserv, 25, 62-70

10. Roh JS, Ahn YS, Kim YG, Min SH (2013) Consumer's willingness to pay for the GAP medicinal crop. Korean J Agric Manage Policy, 40, 894-921

11. Park KI, Oh JM (2011) Effects of Liriopis tuber water extract on RANKL-induced osteoclast differentiation. Korean J Phys Anthropol, 24, 237-244

12. Park SD, Lee GH, Lee YS, Kwon YK, Park JH, Choi SM, Shin SW (2007) Comparison of immunomodualtory effects of water-extracted Adenophorae radix, Liriopis tuber, Dendrobii Herba, Polygonati odorati Rhizoma and Polygonati Rhizoma. Korean J Orient Pathol, 21, 414-424

13. Back NI, Cho SJ, Bang MH, Lee IZ, Park CG, Kim MS, Kim KS, Sung JD (1998) Pesticide environment chemistry. Cytotoxicity of steroid saponins from the tuber of Liriope platyphylla WT. Agric Chem Biotechnol, 41, 390-394

14. Nam SH, Choi SI, Goo JS, Kim JE, Lee YK, Hwang IS, Lee HR, Lee YJ, Lee HG, Choi YW, Hwang DY (2011) LP-M, a Novel butanol-extracts isolated from Liriope platyphylla, could induce the neuronal cell survival and neurotic outgrowth in hippocampus of mice through Akt/ERK activation on NGF signal pathway. J Life Sci, 21, 1234-1243

15. Rhee IJ, An JY (2003) Hepatoprotective effects of water extract of Liriopis tuber on carbon tetrachloride-induced hepatotoxicity in rats. Korean J Pharmacogn, 34, 166-171

16. Kim SD, Ku YS, Lee IZ, Kim MK, Park IK (2000) Major chemical components in fermented beverages of Liriopis tuber. J East Asian Soc Diet Life, 10, 281-287

17. Lee KS, Kim GH, Seong BJ, Kim HH, Song MR, Kim 
MR, Lee GH (2010) Physiochemical characteristics of ginseng Jungkwa produced with hot-water extract from Maegmundong (Liriope platyphylla tubers). J Korean Soc Food Sci Nutr, 39, 1819-1825

18. Lee YK, Lee MY, Kim SD (2004) Quality characteristics and dietary effect of baguette bread added with water extracts of Liriopis tuber on the blood glucose and serum cholesterol in diabetes induced rats. J East Asian Soc Diet Life, 14, 275-282

19. Kim HY, Kim JY, Cho EJ, Choi JM, Hwang CE, Lee HY, Ahn MJ, Lee JH, Kim YG, Ko KH, Goo YM, Oh KY, Cho KM (2015) Free radical scavenging effect and oxidative stress protective activity of domestic processed Polygoni multiflori radix. J Korean Soc Food Sci Nutr, 44, 809-815

20. Han HJ, Kim HJ, Chong MC, Cho HE, Choi YH, Lee KN (2009) Effect of red ginseng with processed sulfur extracts on serum lipids concentration and metabolic variables in diabetic rats. Korea J Herbology, 24, 89-98

21. Yang MO (2013) Antioxidant and sensory properties of hot water extract of Liriope tubers treated at various preprocess. J East Asian Soc Diet Life, 23, 645-653

22. Kim YR, Ha JH, Kim SR, Park YC, Kim KC, Kim WI, Ryu SH, Kim HY (2016) Investigation of microbial contamination in Liriope platyphylla at post harvest environments. J Food Hyg Saf, 31, 99-106

23. Kim JW, Kim SD, Youn KS (2011) Antioxidant activity of Hwangki and Beni-Koji extracts and mixture. J Korean Soc Food Sci Nutr, 40, 1-6

24. Blois MS (1958) Antioxidant determinations by the use of a stable free radical. Nature, 181, 1199-1200

25. Re R, Pellegrini N, Proteggente A, Pannala A, Yang M, Rice-Evans C (1999) Antioxidant activity applying an improved ABTS radical cation decolorization assay. Free Radical Biol Med, 26, 1231-1237

26. Benzie IFF, Strain JJ (1996) The ferric reducing ability of plasma (FRAP) as a measure of "Antioxidant power": The FRAP assay. Anal Biochem, 230, 70-79

27. Bae KM, Park SH, Jung KH, Kim MJ, Hong SH, Song YO, Lee HS (2010) Effects of roasting conditions on physicochemical properties and sensory properties of Liriopis tuber. J Korean Soc Food Sci Nutr, 39, 1503-1508

28. Lee JW, Lee SK, Do JH, Shim KH (1998) Characteristics of the water soluble browning reaction of Korean red ginseng as affected by heating treatment. J Ginseng Res, 22, 193-199
29. Ryu KC, Chung HW (1989) Effect of roasting conditions on quality and yields of barley tea. Korean J Food Sci Technol, 21, 575-582

30. Choi JH, Kim WJ, Yang JW, Sung HS, Hong SK (1981) Quality changes in red ginseng extract during high temperature storage. J Korean Agric Chem Soc, 24, 50-58

31. Saunders J, Jervis F (1966) The role of buffer salts in non-enzymatic browning. J Sci Food Agric, 17, 245-249

32. Choi YH, Kim KH, Kang MY (2001) Varietal difference in processing and sensory characteristics of "Sikhe" in rice. Korean J Breed, 33, 65-72

33. Kang KM, Lee SH (2013) Effects of extraction methods on the antioxidative activity of Artemisia sp. J Korean Soc Food Sci Nutr, 42, 1249-1254

34. Nam S, Kwon YR, Youn KS (2017) Physicochemical properties of acorn (Quercus acutissima Carr.) tea depending on steaming and hot-air drying treatments. Korean J Food Preserv, 24, 21-26

35. Lee KS, Kim GH, Kim HH, Choi JW, Lee HC, Song MR, Kim MR, Lee GH (2009) Physicochemical characteristics of Liriope platyphylla tubers by drying process. J Korean Soc Food Sci Nutr, 38, 1104-1110

36. Kim SD, Ku YS, Lee IZ, Kim ID, Youn KS (2001) General components and sensory evaluation of hot water extract from Liriopis tuber. J Korean Soc Food Sci Nutr, $30,20-24$

37. Tomota M, Kato S (1966) Water soluble carbohydrates of ophiopogonins tuber. I. Isolation and determination of monosaccharides and oilgosaccharides. Soyakugaku Zasshi, 20, 12-14

38. Tomoda M, Kato S (1968) Water soluble carbohydrates of ophiopogon tuber. II. purification, properties and structures of three oligosaccharides. Chem Pharm Bull, 16, $113-116$

39. Lee DY, Son KH, Do JC, Kang SS (1989) The new steroidal saponins from the tuber of Lirope spocata. Arch Pharmacal Res, 12, 295-299

40. Kang DH, Kim SY (2008) Comparison of nerve growth factor inducrion by butanol fraction of Liriope platyphylla and Ophiopogon japoncus. Korean J Pharmacogn, 39, 75-79

41. Hur JY, Lee PJ, Kim JM, Kim AJ, Kim HC, Kim SY (2004) Induction of nerve growth factor by butanol fraction of Liriope platyphylla in $\mathrm{C} 6$ and primary astrocyte cells. Biol Pharm Bull, 27, 1257-1260

42. Nam KY, Lee NR, Moon BD Song GY, Shin HS, Choi JE (2012) Changes of ginsenosides and color from black 
ginsengs prepared by steaming-drying cycles. Korean J Med Crop Sci, 20, 27-35

43. Choi WS (2012) Development of functional beverage using yam (Dioscorea opposita Thunb.). Food Ind Nutr, $17,20-22$

44. Song SB, Ko JY, Kim JI, Lee JS, Jung TW, Kim KY, Kwak DY, Oh IS, Woo KS (2013) Changes in physicochemical characteristics and antioxidant activity of adzuki bean and adzuki bean tea depending on the variety and roasting time. J Food Sci Technol, 45, 317-324

45. Cho KM, Joo OS (2012) Enhances antioxidant effect of purple sweet potato by roasting. Korean J Food Preserv, $19,735-743$
46. Do JH, Kim KH, Jang JG, Yang JW, Lee KS (1989) Changes in color intensity and components during browning reaction of white ginseng water extract. Korean J Food Sci Technol, 21, 480-485

47. Nicoli MC, Anese M, Manzocco L, Lerici CR (1997) Antioxidant properties of coffee brews in relation to the roasting degree. LWT-Food Sci Technol, 30, 292-297

48. Lee SH, Hwang IG, Lee YR, Joung EM, Jeong HS, Lee HB (2009) Physicochemical characteristics and antioxidant activity of heated radish (Raphanus sativus L.) extracts. J Korean Soc Food Sci Nutr, 38, 490-495

49. Kim HY, Woo KS, Hwang IG, Lee YR, Jeong HS (2008) Effects of heat treatments on the antioxidant activities of fruits and vegetables. Korean J Food Sci Technol, 40, 166-170 